\title{
Curriculum development in South Africa: the role of professional bodies
}

\section{Musimuni Dowelani ${ }^{1}$, Faith Dowelani ${ }^{2}$}

${ }^{1}$ Department of Finance and Investment, University of Johannesburg, South Africa, ${ }^{2}$ Department of Construction Economics, University of Pretoria, South Africa.

\begin{abstract}
The function and main goal of higher education has evolved over time; studies show that there is a shift in focus from pure intellectual exploration to job preparation. Curriculum development literature argues that the collaboration between universities and industries is critical for skills development and provides alignment between skills required in the workplace and skills transferred through higher education. This desk study aimed to synthesis the role of professional bodies as representatives of industry in curriculum development in the South African context. Observations show that a significant number of professional bodies mandate curriculum, by accrediting qualifications offered by universities. Not all programs require professional body accreditation or approval, however approximately $60 \%$ of all university programmes in South Africa are subject to the accreditation of professional associations. Without the accreditation from professional bodies, universities would not be able to offer qualifications in certain disciplines such as health and engineering. There is evidence that professional body involvement in curriculum development ascertains a level of quality.
\end{abstract}

Keywords: Curriculum development; Professional bodies; Higher education. 


\section{Introduction}

Higher education institutions in developing countries are experiencing a growing gap between their curricula and the demands from employers and other stakeholders (Kouwenhoven, 2010). Academics have historically and traditionally been at the centre of curriculum development and have had the sole responsibility to develop the curriculum consulting stakeholders for feedback only once the curricula were ready (Walkington, 2002). However, curricula should be a combination of what the industry, employers and other stakeholders are looking for in an employee and the learning interests of students (Alfredo \& Bonilla, 2012), this has not been the case (Tessema \& Abejehu, 2017).

Curriculum development literature argues for strong collaborations between universities and industry (Zanko, Papadopoulos, Taylor, Fallshaw, \& Lawson, 2011; Bennett, 2006; Herrington \& Herrington, 2006; Kiggins, Cambourne, \& Ferry,2005), this is supported by the World Bank that also affirms that the collaboration between universities and industries is critical for skills development and provides alignment between skills required in the workplace and skills transferred through higher education (Larsen, Bandara, Esham, \& Unantenne, 2016).

A contemporary approach to curriculum development allows for collaboration with targeted stakeholders as part of the development process (Keogh, Fourie, Watson \& Gay, 2010). This allows for a broader holistic view of curriculum development, which allows for a curriculum that meets the needs of the students, employers, government and other stakeholders. Keogh et al. (2010) identify professional bodies as targeted stakeholders in the curriculum development process. Professional bodies are formed by the members of a profession with the aim to regulate practices, make sure that individuals who practice in the profession are qualified and competent, and play a disciplinary function to protect the Code of Conduct. Some professional bodies assure the competence of practising professionals by monitoring the content of education programme in universities (Harvey, Mason \& Ward,1995) by participating in the curriculum development; through the accreditation of courses/programs offered by higher education institutions (Chandrasekaran, Stojcevski, Littlefair \& Joordens, 2013)..

The principle of accreditation of higher education degree programmes by associated professional bodies is a widely accepted practice globally (Rawel, 2002, Mabizela, Ballim, $\&$ Mubangizi, 2014). Accreditation is 'a process of quality control and assurance in higher education, whereby, as a result of inspection or assessment, or both, an institution or its programmes are recognised as meeting minimum acceptable standards' (Adelman, 1992). The rationale for this practice of programme accreditation is to create uniformity across the sector (Harvey, 2004). The aim of this study was to synthesis the role of professional bodies as stakeholders in curriculum development in the South African context. 


\section{Observations}

There are 26 public universities in South Africa with the youngest two established in Mpumalanga and the Northern Cape provinces during 2014/2015. The study summarises seven faculties, from the top five universities in South Africa namely, the University of the Witwatersrand (Wits), the University of Cape Town (UCT), the University of Pretoria (UP), Stellenbosch University (SU) and the University of Johannesburg (UJ). A list of professional bodies sourced from South African Qualification Authority (SAQA), additional information on the role of each professional body was sourced from university and professional bodies' websites. The list had 107 registered professional bodies, $15.8 \%$ of the professional bodies are statutory bodies belonging to the Faculties of Health Sciences and the Faculty of Engineering and Built Environment..

\subsection{Faculty of Health Science}

"Health professions are subject to legal and voluntary requirements or guidelines related to ensuring the competence of practising professionals, practice standards, and professional and patient protections" (Stobo, Salmon, \& Cohn, 2002). In South Africa, there are three main health statutory professional bodies; Health Professions Council of South Africa (HPCSA), South African Nursing Council (SANC) and the South African Pharmacy Council (SAPC). The Health Professions Act No. 56 of 1974, allows the HPCSA to have control over the education, training and registration for practice of healthcare professions registered under the Act. The HPCSA has 12 professional boards, as seen in Figure 1 that are responsible for providing guidance and informed curriculum development processes, and ensuring adherence by training institutions to the Board's core competencies and training framework.

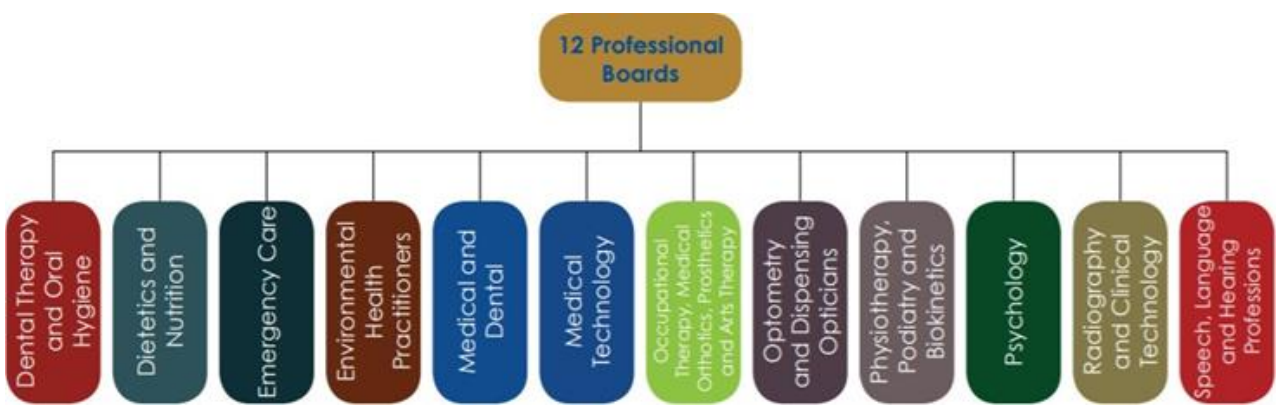

Figure 1. The 12 Professional Boards of the HPCSA. Source: HPCSA annual report 2018/19.

The educational framework for curriculum in universities and higher education institutions that offer qualifications in nursing is based on recommendations from the SANC which is regulated by the Nursing Act No.33 of 2005 . The Act was passed to provide for the statutory control of the nursing and midwifery professions by nurses. The same applies to the 
curriculum taught in pharmacy which is regulated Pharmacy Act 53 of 1974. Although the SAPC is not prescriptive regarding the form and structure of the learning material that will be used to implement the curriculum, it is nevertheless still important to indicate how the content will be covered in the curricular content and is comprehensively described in the curriculum document drafted by the Council.

\subsection{Faculty of Engineering, Built Environment and Information Technology}

Information Technology degree programmes in South Africa do not have a professional body that accredits degrees or reviews curriculum (Ponelis, Matthee, Buckley, Kroeze, Venter, \& Pretorius, 2012). However, The Institute of Information Technology Professionals South Africa (IITPSA) and South African Institute of Computer Scientists and Information Technologists (SAICSIT) regulate the professional conduct of their members and provide further educational development to their members. Professionals do not have to be a member of either institute to practise or work in the industry.Table 1 provides a summary of the professions, professional bodies and Acts.

Table 1. Faculty of Engineering, Built Environment Professional bodies.

\begin{tabular}{|c|c|c|}
\hline Profession & Professional body & Act \\
\hline Engineering & $\begin{array}{l}\text { Engineering Council of South Africa } \\
\text { (ECSA) }\end{array}$ & $\begin{array}{l}\text { Engineering Profession Act } 46 \\
\text { of } 2000\end{array}$ \\
\hline Quantity Surveying & $\begin{array}{l}\text { South African Council the Quantity } \\
\text { Surveying Profession (SACAQSP) }\end{array}$ & $\begin{array}{l}\text { Quantity Surveying Profession } \\
\text { Act } 49 \text { of } 2000\end{array}$ \\
\hline Architectural & $\begin{array}{l}\text { South African Council for the } \\
\text { Architectural Profession (SACAP) }\end{array}$ & $\begin{array}{l}\text { Architectural Profession Act } \\
44 \text { of } 2000\end{array}$ \\
\hline Landscape & $\begin{array}{l}\text { South African Council the Landscape } \\
\text { Architectural Profession (SALAP) }\end{array}$ & $\begin{array}{l}\text { Landscape Architectural } \\
\text { Profession Act } 45 \text { of } 2000\end{array}$ \\
\hline $\begin{array}{l}\text { Project and Construction } \\
\text { Management }\end{array}$ & $\begin{array}{l}\text { South African Council for the Project and } \\
\text { Construction Management Profession } \\
\text { (SACPCMP) }\end{array}$ & $\begin{array}{l}\text { Project and Construction } \\
\text { Management Profession Act } \\
48 \text { of } 2000\end{array}$ \\
\hline
\end{tabular}

The Engineering and Built Environment Professions have six Councils coordinated by Council for the Built Environment (CBE), a statutory body established under the Council for the Built Environment Act No.43 of 2000. Each Council is governed by an act; the Act empowers the Council to conduct accreditation visits to universities to evaluate educational programmes. In order to assess the quality and relevance of each of the qualifications offered by universities. The Councils determine themes that describe the body of knowledge that 
must be incorporated in programmes as modules or sub-modules. However, Councils do not prescribe how the themes may be designed in the programme. Each Council independently conducts accreditation visits to universities to evaluate educational programmes. The purpose of accreditation in the CBE disciplines is to ensure that the undergraduate courses offered bySouth African universities are of a sufficient standard for graduates to work as CBE professional in SA (Maneschijn, \& Bester, 2016).

\subsection{Faculty of Economic and Management Sciences}

The professions in the faculty and the professional bodies' participation are summarised in table 2. The involvement of professional bodies in this faculty range from advisory to, prescribing curriculum and accrediting degrees programmes.

\subsection{Faculty of Education, Law and Humanities}

The professional body for teacher education, the South African Council for Educators (SACE), unlike councils for other professions such as Engineering, Accounting or Health, does not regulate and quality assure the development of higher education qualifications employment (Parker \& Adler,2005). The Law Society of South Africa (LSSA) has always had minimal involvement in the quality assurance of legal programmes offered by South African universities (Mabizela, Ballim \& Mubangizi, 2014). However, in recent years they have worked very closely with the South African Law Deans Association and the General Council of the Bar to improve the quality and uniformity of law degrees in South Africa (LSSA, 2017).

Faculty of Humanities can be divided into the following disciplines: music, visual and performing arts, languages, linguistics and literature, philosophy, sociology, social work, religion and theology, and history. Social work is the only discipline with statutory body in the faculty, the South African Council for Social Service Professions (SACSSP). The SACSSP is the professional statutory body that regulates the educational requirements, professional registration and professional conduct of members of the profession. Social Service Professions Act No.110 of 1978. Students studying towards a social work degree are required to register with the SACSSP before the commencement of the second year of their degree and some universities expect students to take a public oath to uphold the SACSSP code of ethics. Some disciplines have professional association for example the South African Sociological Association established in 1993 and The Association for Ministry Training Practitioners (AMTP) established in 2014. 
Curriculum development in South Africa: the role of professional bodies

Table 2. Faculty of Economic and Management Sciences Professional bodies

\begin{tabular}{|c|c|c|}
\hline Profession & Professional body & Role of Professional body \\
\hline \multirow[t]{4}{*}{ Accounting } & $\begin{array}{l}\text { South African Institute of Chartered } \\
\text { Accountants (SAICA) }\end{array}$ & $\begin{array}{l}\text { Prescribes curriculum and } \\
\text { accredits degrees }\end{array}$ \\
\hline & $\begin{array}{l}\text { Association of Charted Certified Accountants } \\
\text { (ACCA) }\end{array}$ & $\begin{array}{l}\text { Prescribes curriculum and } \\
\text { accredits degrees }\end{array}$ \\
\hline & $\begin{array}{c}\text { Commercial and Financial Accounts South } \\
\text { Africa (CFA) }\end{array}$ & Prescribes curriculum \\
\hline & $\begin{array}{l}\text { South African Institute of Professional } \\
\text { Accountants (SAIPA) }\end{array}$ & $\begin{array}{l}\text { Prescribes curriculum and } \\
\text { accredits degrees }\end{array}$ \\
\hline $\begin{array}{c}\text { Financial } \\
\text { management }\end{array}$ & $\begin{array}{l}\text { Charted Institute of Management Accountants } \\
\text { (CIMA) }\end{array}$ & $\begin{array}{l}\text { Prescribes curriculum and } \\
\text { accredits degrees }\end{array}$ \\
\hline $\begin{array}{l}\text { Investment } \\
\text { management }\end{array}$ & Charted Financial Analyst (CFA) & $\begin{array}{l}\text { Prescribes curriculum and } \\
\text { accredits degrees }\end{array}$ \\
\hline Auditing & Institute of Internal Auditors (IIA) & $\begin{array}{l}\text { Prescribes curriculum and } \\
\text { accredits degrees }\end{array}$ \\
\hline $\operatorname{Tax}$ & $\begin{array}{l}\text { South African Institute of Tax Practitioners } \\
\text { (SAIT) }\end{array}$ & Advisory \\
\hline Economics & $\begin{array}{l}\text { Economics Association of Southern Africa } \\
\text { (ESSA) }\end{array}$ & Advisory \\
\hline $\begin{array}{c}\text { Business } \\
\text { Management }\end{array}$ & $\begin{array}{l}\text { Southern African Institute for Management } \\
\text { Scientist (SAIMS) }\end{array}$ & Accredits degree \\
\hline $\begin{array}{c}\text { Human } \\
\text { Resource } \\
\text { management }\end{array}$ & $\begin{array}{l}\text { South African Board of Personnel Practice } \\
\text { (SABPP) }\end{array}$ & $\begin{array}{l}\text { Prescribes curriculum and } \\
\text { accredits degrees }\end{array}$ \\
\hline Marketing and & Marketing Federation of South Africa (MFSA) & Accredits degree \\
\hline $\begin{array}{l}\text { Communication } \\
\text { Management }\end{array}$ & $\begin{array}{l}\text { Public Relations Institute of South Africa } \\
\text { (PRISA) }\end{array}$ & $\begin{array}{l}\text { Prescribes curriculum and } \\
\text { accredits degrees }\end{array}$ \\
\hline Public & South African Association of Public & Advisory \\
\hline Administration & Administration (SAAPA) & \\
\hline
\end{tabular}

\subsection{Faculty of Natural and Agricultural Sciences}

Departments/ schools of Actuarial Science operate within the regulations of the Actuarial Society of SA (ASSA) and its Board; which prescribes $95 \%$ of the content/outcomes of the 
curriculum. Actuarial Science syllabus is revised every five years in line with international and South African actuarial practice. ASSA uses the curriculum of the Joint Board of the Institute/Faculty of Actuaries, UK. The South African Council for Natural Scientific Professions (SACNCP) is responsible for the registration and regulation of practising professional in the fields of agricultural science, animal science, aquatic science, biological science, chemical science, earth science, ecological science, environmental science, food science, geological science, applied mathematics, operations research, microbiological sciences, water resources, and zoological science. The SACNCP and its registered persons play a collaborative and advisory role in higher education. The SACNCP does not accredit or prescribe curriculum in degree programmes. In addition to SACNCP the Faculty has 48 voluntary bodies. Below are three examples and how they participate:

- The Statistical Association of South Africa (SASA) communicates regularly on education initiatives in the country plays an advisory role in the curriculum development process.

- The School of Physics has made considered contributions to the Review of Undergraduate Physics Education, which was coordinated by the Council for Higher Education and the South African Institute of Physics (SAIP).

- Minerals Education Trust Fund (METF) evaluates all Geology Curricula on offer in South Africa and supports whatever initiatives it can at all Universities

\section{Concluding remarks}

The engagement and collaboration between universities and professional bodies are both desirable and inevitable. Professional bodies play a quality assurance role in higher education by setting, maintaining and monitoring educational and professional qualifications. Through competency frameworks, professional bodies are able to detail what must be included in curricula and syllabi. The accreditation of university programmes is a common practice globally; the accreditation process is viewed as an external quality assurance tool. This study observed that some fields have a strong dominance of professional bodies mandated by law, for example Health Science and Engineering and Built environment. However, not all programmes require professional body accreditation or approval, approximately $60 \%$ of all university programmes in South Africa are subject to the accreditation of professional associations.

\section{References}

Adelman, C. (1992). Accreditation. The encyclopedia of higher education, 1, 1313-1318. 
Bennett, S. (2006). Using related case studies to support authentic project activities, In A. Herrington, \& J. Herrington (Eds.), Authentic learning environments in higher education. London: Information SciencePublishing. .120-134.

Chandrasekaran, S., Stojcevski, A., Littlefair, G., \& Joordens, M. (2013, January). Accreditation inspired project oriented design based learning curriculum for engineering education. In IETEC 2013: Enhancing Global Engineering and Technology Education: Meeting the Future: Proceedings of the 2nd International Engineering and Technology Education Conference 2013 ( 1-11). University of Technical Education, Ho Chi Minh City.

Harvey, L., Mason, S., \& Ward, R. (1995). The role of professional bodies in higher education quality monitoring. Birmingham: QHE.

Harvey, L. (2004). The power of accreditation: Views of academics. Journal of Higher Education Policy and Management, 26:2, 207-223.

The Health Professions Council of South Africa. 2019. 2017/2018 annual report of the Health Professions Council of South Africa. Retrieved from. https://www.hpcsa.co.za/Uploads/ editor/Userfiles/downloads/publications/annual_reports/hpcsa_annual_report_2017_201 8.pdf.

Keogh, J. J., Fourie, W. J., Watson, S., \& Gay, H. (2010). Involving the stakeholders in the curriculum process: A recipe for success?. Nurse education today, 30:1, 37-43.

Herrington, A., \& Herrington J. (Eds.). (2006). Authentic learning environments in higher education. London:Information Science Publishing.

Kiggins, J., Cambourne, B., \& Ferry, B. (2005). Re-organising and integrating the knowledge bases of initial teacher education: the knowledge building community program. In G. Hoban (Ed.), The missing links in teacher education: innovative approaches to designing teacher education programs. Dordrecht, The Netherlands: Springer. 75-94.

Kouwenhoven, W. (2010). Competence-based curriculum development in higher education: Some African experiences. Access \& expansion: Challenges or higher education improvement in developing countries, 125-146.

Larsen, K., Bandara, D. C., Esham, M., \& Unantenne, R. (2016). Promoting universityindustry collaboration in Sri Lanka: status, case studies, and policy options. The World Bank.

Law Society of South Africa. 2017. LEGAL EDUCATION IN CRISIS? Law Deans and the Legal Profession set to discuss refinement of LLB degree. [Press release]. Retrieved from https://www.lssa.org.za/upload/documents/LLB\%20SUMMIT\%20PRESS\%20RELEAS E.pdf

Mabizela, S., Ballim, Y., \& Mubangizi, J. C. (2014). Professional bodies and quality assurance of higher education programmes in South Africa: Towards an appropriate framework. South African journal of higher education, 28:4, 1140-1155.

Maneschijn, A., \& Bester, C. R. (2016, April). Undergraduate mechanical engineering design courses at the University of Johannesburg from an accreditation perspective. In 2016 IEEE Global Engineering Education Conference (EDUCON) .361-368. IEEE. 
Mashile, E. O. (2002). Continuous professional development of educators: the state, professional councils and higher education. South African journal of higher education, $16: 1,174-182$.

Parker, D., \& Adler, J. (2005). Constraint or catalyst? The regulation of teacher education in South Africa. Journal of Education, 36:1, 59-78.

Ponelis, S. R., Matthee, M. C., Buckley, S., Kroeze, J. H., Venter, I. M., \& Pretorius, P. D. (2012, December). Building capacity and developing human capital: an exploration of curriculum development in ICT programmes at South African universities. In Proceedings of SIG GlobDev Fifth Annual Workshop, Orlando, FL, 16.

Rawel, A. (2002). How far do professional associations influence the direction of public relations education? Journal of Communication Management, 7(1), 71-78. Retrieved from https://search.proquest.com/docview/232935426?accountid=13425

Stobo, J. D., Salmon, M. E., \& Cohn, F. (Eds.). (2002). Confronting chronic neglect: the education and training of health professionals on family violence. National Academies Press.

Tessema, B. S., \& Abejehu, S. B. (2017). University-Industry Collaboration in Curriculum Development: Analysis of Banking and Finance Graduates' Attributes from Educators and Industries Perspective. Education Journal, 6:2, 87-93.

Venter, ER \& C de Villiers 2013. The Accounting Profession's Influence on Academe: South African Evidence. Accounting, Auditing \& Accountability Journal, 26:8, 1246-1278.

Walkington, J. (2002). A process for curriculum change in engineering education. European Journal of Engineering Education, 27:2, 133-148.

Zanko, M., Papadopoulos, T., Taylor, T., Fallshaw, E., \& Lawson, R. (2011). Professional learning in the business curriculum: Engaging industry, academics and students. 